\title{
Total Quality Management to reduce cost and To Improve Quality Process in Education Institution
}

\author{
Safar Bakheet Almudara ${ }^{1}$
}

\begin{tabular}{l} 
ARTICLE INFO \\
\hline Article History: \\
Received 13.12.2017 \\
Received in revised form \\
06.02.1018 \\
Accepted \\
Available online 01.04 .2018
\end{tabular}

\section{INTRODUCTION}

\begin{abstract}
It is observed that admissions to the institution is directly proportional to the student graduation and their job placement. Hence, it is very important for the institution to maintain college quality process intact and at the same time to find ways to reduce cost. In this paper author arg ues that Total Quality Management(TQM) helps to reduce cost and improves quality process. Author has designed TQM for the educational institution for reducing cost and keeping in mind quality process. Author has suggested new techniques and it is borrowed from the TQM, for pursuing new strategic thinking it is mandatory for quality team to carefully consider activities for the for the strategic planning. The quality process within institutions is assigned to a particular body consisting of faculty members from selected departments. This body, conveys with other teaching staff about the quality process and evaluation and draws up the institutions mission, vision and objectives. With this approach the quality department will have to depend on the expertise to evaluate their efforts, most likely it is observed that this kind of approach has always failed to achieve its objectives. Once, the strategic plan is charted out then quality process has to be concentrating more on prevention rather correcting during the process or phase itself. This phase created by the core quality team in collaboration with department's quality team. In the fashion the total quality management can be utilized to achieve in educational institution.
\end{abstract}

CC 2018 IJERE. All rights reserved

Keywords:

Total Quality Management, Quality Process, Education institutions, Work breakdown system.

Quality education is defined as the degree to which institution educates students and increases the likelihood of intended outcomes of the program with peer institution. This definition allows for an understanding of quality education as a composite system embedded in an economic context. Quality cost is consists of two categories, one, it is the cost of achieving good quality graduates and secondly, cost of poor quality, it means that internal or external failure cost (Sperling, 2017; Ryan, 2017; Walker, 2017).

On other hand cost reduction is a practice to reduce costs and increase profits (Boardman, 2017; Hovenkamp, 2015). Practice to reduce cost is based on the services and product, because the process of product development is affected by the cost. Similarly, institutions are reducing cost by various methods, specifically, by improving the quality while keeping the cost low (Drummond, 2015). The major aim of universities is to utilize all teaching and non-teaching members to achieve the quality goals. Because cost reduce and quality improvement initiative infuses education sector. Indeed, stakeholders and national framew ork for assessment to judge the universities and their system in terms of intended outcomes.

It is very well know that quality costs increases as the detection point moves up the student graduating and their employment (Vinichenko, 2016; Finch, 2016). When universities unable to meet the mission and vision in the first place, then it is generally most expensive to find quality cost, it also means students are not employed or unable to compete in the job market. Hence, early detection delivers great significant feedback to recognize root causes. The time lag between admission and failure or not securing a job makes it very difficult to identify the rate at which students are admitted, dropped and uncompleted. Hence, alumni department is useful in prospectively evaluating a solution is of little help in retrospectively evaluating a problem of not meeting the mission and vision. Hence, framew ork of quality and cost reduction methods should be integrated along with the program plan and specification time only (Sallis, 2014).

\section{Aim of the Study}

To demonstrate the quality of education, it depends many entities of an institution. While, rate at which graduates securing jobs will also provide needed improvement and attribute national, State, or other level of 
Almudara,S.B. (2018). Total quality management to reduce cost and to improve quality process in education institution. International Journal of Educational Research Review,3(2),23-29.

quality framework. Hence, one can also derive failure to meet the mission and vision and additionally it gives us efforts needed to bring back the quality process back into satisfactory range. Quality satisfactory range is range of high number of qualifying graduates and securing jobs in the market than the most recent years.

In this paper author is proposing a framew ork of quality cost reduction and keeping the quality at its satisfactory range. Initially author identifies what's the quality cost of the present system and finding of ways to reduce it. Lastly analytically comparing with the proposed framework.

\section{LITERATURE REVIEW}

Quality improvement and cost reduction in manufacturing (Majumder, 2017), health center (Bozic , 2014; Macano,2017; Porter, 2010; Hong, 1995;) and universities are being continuously pursued.

In health care centers, people think it's a tradeoff. However, from the patients perspective, health care center make care better and more affordable paying for insurance. So challenge is that quality and cost should be considered together by reducing the waste. In very recently published (Macano,2017; Porter, 2010), it is mentioned that reducing admission of patient to the hospital by rendering emergency services, swift assessment and management of patients. Following are the highlights from the research (Macano, 2017).

- Most emergency surgery patients can be initially managed on an urgent outpatient basis. (Macano, 2017)

- Guidelines for referral to an emergency surgical clinic reduces inappropriate referrals. (Macano, 2017)

- An ambulatory care clinic reduces hospital admission. (Macano, 2017)

According to Macano, patients can be primarily directed as an urgent outpatient. It can reduce unsuitable recommendations of patients. An ambulatory care center reduces hospital admission.

- We estimate the propensity score-the likelihood that a student graduates from a particular college sector (Andrews, 2016).

- We use the propensity score to re-weight the distribution of earnings such that the characteristics of the quality sector under consideration and the Non-Flagship Public Universities are balanced (Andrews, 2016).

- This method is analogous to using survey weights to estimate population quantities using a specific sample (Andrews, 2016.

Furthermore, in (Andrews, 2016) they also found out that there is a need to do more research in finding proper education investment decision apart from mean treatment effects.

Total Quality Management (TQM) can be applied to institution for reducing Quality costs by reducing unwanted steps and methods of a quality process so as to improve efficiency. TQM has proved as best candidate for improving effectiveness, flexibility, efficiency, and competitiveness in any given business. The TQM process involves several steps that educational institutional can apply to reduce quality costs:

\section{Pursue New Strategic Thinking}

When apply new strategies, you should alw ays come up with the way to reduce quality cost.

\section{Total Employee Involvement :}

It is a method of contribution of staffs to administrative success, by leasing them to take accountabilities in the quality procedure. It allows everybody's involvement, by using their skills in tricky solution, knowledge, continuous development, and look for opportunities.

\section{Concentrate on Prevention and Not Correction:}

Most quality personal seek to stop glitches from happening rather than modifying them later. This is a more cost-effective approach.

\section{Reduce Enduring Waste}


Lessening of long-lasting surplus is somewhat that can decrease expenses in any institution. Quality process with a long-lasting surplus lessening policy are characteristically more fruitful in terms of financially since they don't spend excess money.

\section{A Balanced Approach}

To use a stable method in order lessen expenses within an organization. If method is well-adjusted, employee will not be upset with additional costs, or with irrational approaches to diminish superfluous waste.

\section{Use Structured Practice for Process Improvement}

An organized methodology for process improvement is proven to reduce cost. Once expenses are reduced, universities can plough in their excellence services. Hence, this makes universities more efficient. With the setup for process improvement, faculty and their services are also effective. It's within the best interest of the universities to use the structured methodology for process improvement.

\section{Learn to Apply it all}

Guarantee that your workforces recognize o apply the ethics to all services to lessen surplus and budgets within the workplace. It's best to undergo such practices to dominant on these ideologies to exploit the positive effects.

\section{Learn to Set Actual Quality Requirements}

Setting quality opportunities and necessities are vital to the success of the waste and cost reduction methods. Deprived quality requirements, institution will not convey a service that is effective in eliminating surplus and cost.

More-ever, most of the institutions earnings have increased over last several decades. At the same time college graduates' earnings is also recorded high. With this equation students are opting for loans for their universities studies (Black, 2016).

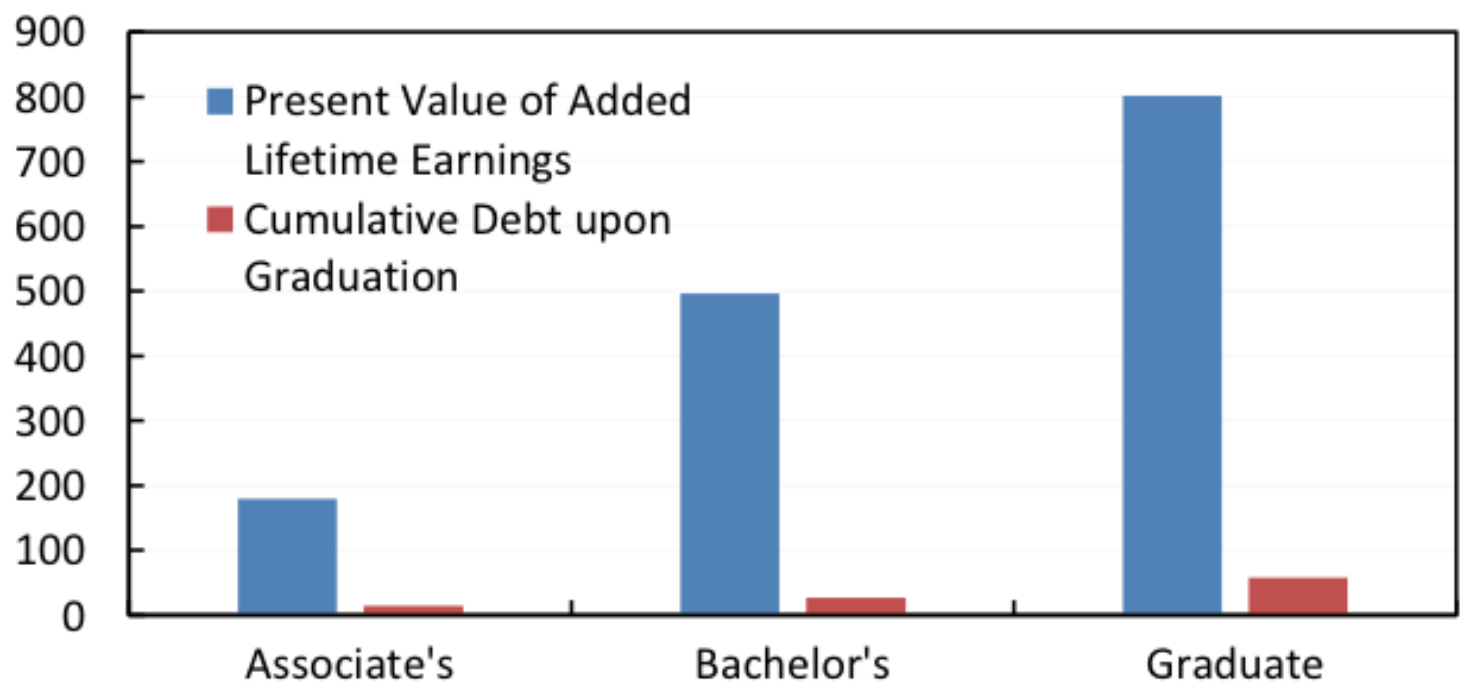

Figure 1 Present value of added lifetime earnings and cumulative student debt, source from (http://voxeu.org)

Whereas, here in gulf countries universities funded by the government never charge a single pie from the students. Yet, they give monthly scholarship for each of the students enrolled in the University for any Graduation Program and apart from this they also invite faculties for research and fund their research projects.

\section{METHODOLOGY OF COST REDUCING WHILE IMPROVING THE QUALITY}

Author demonstrates that lower quality process costs can really help institution by making quality process more productive. It can be achieved by dividing the quality process in different phases which 
capture a significant relationship between quality process and employee. The current quality process deserves an extra work and efforts from employee on quality process and its related operations for each defective process that it produces. Thus, there is an inducement of different phases to produce quality education, and have a smaller phases of defective phases.

The paper uses TQM for quality process in education system for investing in quality improvements: author targets in reducing the probability that the quality process yields fewer defects (Sallis, 2014), (ii) reducing the costs of quality process; and (iii) simultaneously applying these two preferences. Author assumes an exact amount of the investment cost for each phase of the quality procedure, then later on author derives the optimal quality procedure.

Management of Quality process is a significant part of any institution work (Nanda, 2016), the earlier management style can be adapted by the current management form which is named as flexible management, hence, the induction of the flexible management is the key to reduce cost and alter the quality procedure and phases (Michaels, 1994).

Management of any universities are responsible to yield competitive graduates. But, due to the present requirement of the quality process, the present management system in our institution is changed to suite and to yield good results. Author used TQM as mentioned in the literature review for the quality process so as to reduce cost and at the same time to improve the process itself. Following are the process and their activities in tabular form. During the planning phase of the quality process our institution has considered the following guidelines.

- Understanding mission, vision and objectives.

- Question yourself that how we contribute to each of these.

- Stay up-to-date on new methods of teaching, update course material that may result in good response from market analysist.

- Research your institute's major competitors. What are they doing well

- What could be adopted? Where does your institute stand and why?

Table1, shows the strategic planning phase, wherein we clearly mention the activity name, its importance, and people who are involved in this phase of activity. Apart from this, we have to be clearly mention its scope and purpose of the planning.

\begin{tabular}{ccc}
\multicolumn{3}{c}{ Table 1. T Pursue New Strategic Thinking } \\
\hline Activities & Strategic & Strategic \\
& Planning & Thinking \\
What it is & & \\
Importance & \\
Quality & \\
Timeframe & \\
Defining \\
Actions \\
Who's \\
Involved? \\
\hline
\end{tabular}

Describe the scope of the Strategic planning which is under consideration by:

- Explaining what the strategic plan will do;

- Describing the application strategic plan being specified, containing applicable benefits, objectives, and goals;

Define the quality process's correlation to other related process. If this phase is an element of a quality process, then narrate the necessities and importance of quality system to the functionality of the phase covered by the strategic plan. Provide a summary of the major plans that the quality process will be undertaken. Finally, provide a general explanation of any other phases that will limit the institution's options, including: 
- Regulatory policies;

- manpower limitations

- dependency of other phases of quality operation;

- Audit functions;

- Control functions;

- Quality requirements

Table 2, show the total employee involvement planning, quality processing planning is not merely a management concern. Involvement of employee and their contribution is of vital importance. To date, educational institutions have given very less importance to it. The quality process within institutions is assigned to a particular body consisting of faculty members from selected departments. This body, conveys with other teaching staff about the quality process and evaluation and draws up the institutions mission, vision and objectives. With this approach the quality department will have to depend on the expertise to evaluate their efforts, most likely it is observed that this kind of approach has always failed to achieve its objectives. Most of the employees see that they fail to recognize their duties tow ards quality process. From this we can conclude that institutions quality process is deprived from the total employee contribution. But to be successful in achieving mission, vision and objectives of the institution should integrate total management. Hence, each and every department's teaching and non-teaching should contribute to the quality process. In our institution we have utilized total management to enhance quality process and each and every employee has to fill table 2, each table he or she fills will get a score. Based on the services and involvement in the quality process will give them bonus point to earn and rew ard at the end of the academic year.

Table 2. Total Employee Involvement

\begin{tabular}{|c|c|c|c|c|c|}
\hline Acti & Purpose & $\begin{array}{c}\text { Who's } \\
\text { Involved? }\end{array}$ & Dept. & Score & $\begin{array}{c}\text { Most recent } \\
\text { work }\end{array}$ \\
\hline
\end{tabular}

Quality process has to be concentrating more on prevention rather correcting during the process or phase itself. This is phase created by the core quality team in collaboration with department's quality team. Usually, this document once completed will be shared among all the team mates who are involved in the quality process via a planned meet. Sometimes, for an already existing and completed phase, we might not discuss in the meeting. During meeting we plan strategies on what is anticipated at the end of the review meet. Review should start with a title on the page, and its better practice to name the phase for which the review is taking place. For example, if quality review team is reviewing course specification then review document should be "Course Specification" within the title of the review document. Table shows, prevention and not correction phase of the quality process.

Table 3. Concentrate on Prevention and Not Correction

\begin{tabular}{|c|c|c|c|c|c|}
\hline $\begin{array}{l}\text { Quality Plan } \\
\text { code }\end{array}$ & Purpose & Who's Involved? & $\begin{array}{l}\text { Quality Work } \\
\text { or phase }\end{array}$ & $\begin{array}{l}\text { Items } \\
\text { corrected }\end{array}$ & Description \\
\hline
\end{tabular}

This document should convey to team what they're concentrating on quality process and all its different phases to verify and include any other relevant information such as the phase of the quality where the correction is needed, data, and preconditions/assumptions for which the document is altered.

Table 4 , shows reducing the waste, each faculty members are writing course specifications and course reports for their respective courses. They submit these documents in A4 sized paper. On an average it will consume two cartridges for each department and much number of papers. This is really an enduring waste, hence it can be avoided by using softw are and hardware solutions. More ever, computer science department faculty members are capable of building software using any Microsoft languages furthermore, required 
Almudara,S.B. (2018). Total quality management to reduce cost and to improve quality process in education institution. International Journal of Educational Research Review,3 (2),23-29.

hardware is also available. With this arrangement we can avoid the waste which is resultant of quality process.

Table 4. Reduce Enduring Waste

\begin{tabular}{llll}
\hline $\begin{array}{l}\text { Quality } \\
\text { Phases }\end{array}$ & customers financial learning & $\begin{array}{l}\text { Business } \\
\text { processes }\end{array}$ \\
\hline
\end{tabular}

Experienced managers are very well know that project may fails, even though it is planned and executed properly. When we trace back the failed project will give us the knowledge of poor design of the project. Hence, work breakdown structure (WBS) is very important for the project's success. A well planned WBS, is eventually successfully executed as compared to the no planned WBS. Hence, our college quality department team has well aw are of the WBS system, because of this we eliminate many redundant data and dissemination of information. Table, 5 , show s that structured practice for quality process.

Table 5. Use Structured Practice for Process Improvement

\begin{tabular}{llll}
\hline Quality & customers & financial & Learning \\
Phases & & & Business \\
& & & Process
\end{tabular}

\section{CONCLUSION}

Author claims that TQM ability to reduce cost while improving the quality. The important pick in this research is total employee involvement. Which can greatly contribute in reducing cost and improving total quality. In this paper author suggested and proved that TQM and proposed design in the form of tables for improving quality process in line with cost reduction. As this is a proposed solution for reducing cost and maintain quality education. However, implementation of such project will have real time issues which author has never mentioned. But, possibility of achievement of quality education with respect to cost is mentioned. With this knowledge, research community can benefit to deliver more of real implementation. In future, author would also like to implement this framew ork within KSA and surrounding GCC countries.

\section{REFERENCES}

Andrews, R. J., Li, J., \& Lovenheim, M. F. (2016). Quantile treatment effects of college quality on earnings. Journal of Human Resources, 51(1), 200-238.

Black, S., Filipek, A., Furman, J., Giuliano, L., \& Narayan, A. (2016). Student loans and college quality: Effects on borrowers and the economy. https://voxeu.org/print/61000

Boardman, A. E., Greenberg, D. H., Vining, A. R., \& Weimer, D. L. (2017). Cost-benefit analysis: concepts and practice. Cambridge University Press.

Bozic, K. J., Ward, L., Vail, T. P., \& Maze, M. (2014). Bundled payments in total joint arthroplasty: targeting opportunities for quality improvement and cost reduction. Clinical Orthopaedics and Related Research $®$, 472(1), 188-193.

Drummond, M. F., Sculpher, M. J., Claxton, K., Stoddart, G. L., \& Torrance, G. W. (2015). Methods for the economic evaluation of health care programmes. Oxford university press.

Finch, D. J., Peacock, M., Levallet, N., \& Foster, W. (2016). A dynamic capabilities view of employability: Exploring the drivers of competitive advantage for university graduates. Education+ Training, 58(1), 61-81. 
Almudara,S.B. (2018). Total quality management to reduce cost and to improve quality process in education institution. International Journal of Educational Research Review,3(2),23-29.

Hong, J. D., \& Hayya, J. C. (1995). Joint investment in quality improvement and setup reduction. Computers $\mathcal{E}$ Operations Research, 22(6), 567-574.

Hovenkamp, H. (2015). Federal Antitrust Policy, The Law of Competition and Its Practice. West Academic.

Majumder, A., Guchhait, R., \& Sarkar, B. (2017). Manufacturing quality improvement and setup cost reduction in a vendor-buyer supply chain model. European Journal of Industrial Engineering, 11(5), 588-612.

Macano, C. A., Kirby, G. C., Lake, B., Nyasavajjala, S. M., \& Clarke, R. (2017). Surgical assessment clinic-One stop emergency out-patient clinic for rapid assessment, reduced admissions and improved acute surgical service: A quality improvement study. Annals of Medicine and Surgery, 23, 28-31.

Michaels, B. (1994). Flexible management: strategies for the changing workforce. Clinical laboratory management review: official publication of the Clinical Laboratory Management Association, 8(3), 246-249.

Nanda, V. (2016). Quality management system handbook for product development companies. CRC Press.

Porter, M. E. (2010). What is value in health care? New England Journal of Medicine, 363(26), 2477-2481.

Ryan, Y., \& Zuber-Skerritt, O. (Eds.). (2017). Quality in postgraduate education. Routledge.

Sallis, E. (2014). Total quality management in education. Routledge.

Sperling, J. (2017). For-profit higher education: Developing a world class workforce. Routledge.

Vinichenko, M. V., Makushkin, S. A., Melnichuk, A. V., Frolova, E. V., \& Kurbakova, S. N. (2016). Student employment during college studies and after career start. International Review of Management and Marketing, 6(5S).

Walker, R., Reed, M., \& Sutton-Tsang, S. (2017). Effect on students from attending a university degree programmerun in partnership with further and higher education institutions. Journal of Further and Higher Education, 1-10. 